\title{
'IREP EN KEMET' WINE OF ANCIENT EGYPT: DOCUMENTING THE VITICULTURE AND WINEMAKING SCENES IN THE EGYPTIAN TOMBS
}

\author{
M. R. Guasch-Jané ${ }^{\text {a, } * \text {, S. Fonseca }}{ }^{\text {a }}$, M. Ibrahim ${ }^{\text {a }}$ \\ ${ }^{\text {a }}$ Faculty of Social and Human Sciences, Nova University of Lisbon, Av. De Berna 26-C, 1069-061 Lisbon, Portugal - \\ (guasch, fonseca, ibrahim)@wineofancientegypt.com
}

KEY WORDS: Ancient Egypt, Wine, Viticulture, Tombs scenes, Wine jars, Egyptology archives, Database, Website

\begin{abstract}
:
Presented are the research objectives of the project 'Irep en Kemet', Wine of Ancient Egypt, and the content of the project's website. This research aims at documenting the complete corpus of wine in ancient Egypt and analysing the data (iconography, textual sources and artefacts) to unveil the importance of the ancient Egyptian wine culture legacy in the Mediterranean region. At this stage, a bibliographical researchable database relevant to wine, viticulture and winemaking in the ancient Egypt has been completed, with 197 entries including articles, books, chapters in book, academic thesis ( $\mathrm{PhD}$ and MA), essay, abstracts, on-line articles and websites. Moreover, a scene-detail database for the viticulture and winemaking scenes in the Egyptian private tombs has been recorded with 97 entries, some of them unpublished, and the collected data is under study. The titles of the tombs' owners and the texts related to the scenes will be also recorded. A photographic survey of the graves containing images related with viticulture and winemaking will be carried out in order to have the most accurate information on the location and stage of conservation of those images. Our main goal is to provide scholars with a complete, comprehensive archaeological and bibliographical database for the scenes of viticulture and winemaking depicted in the Egyptian private tombs throughout the ancient Egyptian history. The project's website (www.wineofancientegypt.com) will include all the collected data, the study and analysis, the project's history and team members, publications as well as the results of our research.
\end{abstract}

\section{THE 'IREP EN KEMET' PROJECT}

\subsection{Introduction}

One of the world's oldest and most extensive documentation about the viticulture and wine production comes from ancient Egypt. In Egypt, wine was a prestigious product consumed mainly by the upper classes and the royal family. Wine was offered in the daily temple rituals, in funerary offerings (Meyer, 1986) and used in medical treatments.

Viticulture and winemaking scenes are depicted on the walls of the ancient Egyptian private tombs from the Old Kingdom (2575-2150 BC) through the Graeco-Roman times (332 BC-395 AD). Thanks to these scenes, we have information about how the wine was made. Furthermore, the scenes show that the procedures are very similar to the traditional European method (Guasch-Jané 2008; Guasch 2010).

The 'Irep en Kemet', Wine of Ancient Egypt, research project main goal is to document and analyse, for the first time, the complete corpus of viticulture and winemaking scenes depicted on the walls of the Egyptian private tombs, being the most important data to study the history and legacy of wine production in the Mediterranean region.

The traditional European wine elaboration method, which has been used for centuries in the southern European countries like France, Spain, Italy, Portugal or Greece, is considered to come from ancient Greece and Rome. However, the iconographical, archaeological and textual sources from ancient Egypt confirm that the wine was already produced there in the third millennium BC.

'Irep en Kemet' is a three-year scientific project (2011-2013) that is directed by Dr. Maria Rosa Guasch Jané at the Faculdade de Ciencias Sociais e Humanas of the Universidade Nova in Lisbon (Portugal), and funded by the Fundação para a Ciência e a Tecnologia (FCT) of the Portuguese Ministry of Education and Science.

The research team consists of Sofia Fonseca, Archaeologist and Egyptologist, Mahmoud Ibrahim, Egyptologist and Linguist and Maria Rosa Guasch Jané, Pharmacist and Egyptologist.

This paper presents the current stage of our research and the database we are developing, which will be accessible in the project's website, together with the highlights of the research project.

\subsection{Previous research on the colour of Egyptian wines}

Wine jars were placed in the Egyptian tombs as funerary offerings since the Predynastic Period (4000-3100 BC). During the New Kingdom Period (1539-1075 BC), wine jars (amphorae) were inscribed in hieratic to indicate: the vintage year, the name of the product (irp (Erman, 1926) or shedeh (Erman, 1930)), the quality, the provenance, the property (royal or private) and the name and title of the wine-maker.

Like the labels in the modern bottles of wine, the inscriptions on the New Kingdom wine jars give us information about the harvest and wine production (Guasch, 2010). For example, the inscription on the amphora (Journal d'Entrée 62312, Cairo Museum, Carter no. 509) from Tutankhamun's tomb (KV62) at Thebes, reads: "Year 5, sweet wine of the Estate of Aten of the Western River, chief vintner Nakht" (Černy, 1965).

These inscriptions on amphorae reveal that the ancient Egyptians considered this information relevant and necessary to be able to distinguish between wines. It was extremely important to know the vintage and provenance of the product.

\footnotetext{
* Corresponding author.
} 
However, it is curious that no mention was made concerning the colour of wine, either white or red, on the inscriptions or any other documents.

The symbolism of the Egyptian wine was based on its red colour, not only because of the relation established between wine and the blood of the resurrection god Osiris, but also because of the reddish colour of the River Nile during the annual flood -with ferruginous sediments coming from the Ethiopian mountains-, when the harvest time for grapes occurred (Poo, 1986; 1995). In the papyrus of the royal scribe Nakht at the British Museum in London (BM 10471), a vine is leading to the nose of god Osiris as a symbol of resurrection. This symbolism is still in use in Coptic iconography today.

The Egyptian mythology related the wine only to the red colour, and no textual references to white wine -or to red wine- from the Dynastic period (3100-343 BC) have been found in Egypt up to now. The first mention of white wine in Egypt is from Athenaeus of Naucratis, who lived during the 3rd century BC, in his book The Deipnosophistae, where he explains that Mareotis wine, in the area of Lake Mariut near Alexandria, was "excellent, white and enjoyable, aromatic..." (Athenaeus, 1961).

In order to study the kind (colour) of the wines that were made in ancient Egypt, an analytical method (Guasch-Jané, 2004; 2008) for archaeological residues of wine was developed using the liquid chromatography mass spectrometry in tandem (LC/MS/MS) technique. Two compounds were identified in archaeological residue samples from Tutankhamun's amphorae: tartaric acid, as grape marker, and syringic acid derived from malvidin, the latter being the main compound responsible for the red colour of grapes and wines, as red grape marker (Guasch-Jané, 2004; 2006a,b). The results of analysing residue samples from Tutankhamun's amphorae revealed that in ancient Egypt both red and white wines were given the name irp (Guasch-Jané, 2006b; 2008).

The analytical results added new information to the inscription on the amphorae: about the type of wine they contained. There was a red wine in Tutankhamun's amphora Cairo Museum JE 62314, Carter no. 195, (Guasch-Jané, 2006b; 2008) with the inscription "Year 9, wine of the Estate of Aten of the Western River, chief vintner Sennufe" (Černy, 1965), and a white wine was contained in Tutankhamun's amphora JE 62316, Carter no180, (Guasch-Jané, 2006b; 2008) with the inscription "Year 5, wine of the Estate of Tutankhamun, ruler of Thebes, in the Western River, chief vintner Khaa" (Černy, 1965).

The results of these analyses also confirm that in Egypt, during the New Kingdom Period, three kinds of grape products were made (Guasch-Jané, 2008): red wine, white wine and the shedeh, a red wine with a different preparation.

The origin and nature of the shedeh, which has no translation, was a mystery since a century ago, with pomegranates or grapes having been proposed as a raw material. According to Papyrus Salt 825 at the British Museum (BM 10051) of the Late Period (715-332 BC), the only text found so far that mentions the elaboration of the shedeh, it was filtered and heated; nevertheless, due to a damage in the Salt papyrus, the botanical source of shedeh remained unknown (Derchain, 1965; Tallet, 1995; Guasch-Jané, 2008; Tallet 2010).

The results of analysing a sample of a residue from the shedeh amphora JE 62315, Carter no. 206, found in Tutankhamun's Burial chamber, bearing the inscription "Year 5, shedeh of very good quality of the Estate of Aten of the Western River, chief vintner Rer" (Černy, 1965) confirmed that shedeh was a red grape wine (Guasch-Jané, 2006a; 2008).

Recent research suggested the use of the three wine amphorae found in Tutankhamun's Burial chamber (the western amphora containing a red wine, the eastern amphora a white wine and the southern amphora containing shedeh) were for the King's threestep resurrection ritual (Guasch-Jané, 2011).

\section{VITICULTURE AND WINEMAKING SCENES}

\subsection{Overview}

Although several studies and researches were undertaken to resume and catalogue the scenes of viticulture and winemaking in the Egyptian tombs (Wegner, 1933; Lerstrup, 1992; Lesko, 1996; James, 1996; Tallet, 1998; Murray, 2000; Guasch-Jané, 2008), it has not been compiled and analysed in depth until now.

The reliefs and paintings in the ancient Egyptian private tombs depict the different steps of viticulture and winemaking including grape harvest, treading, pressing, fermentation, closing the jars, stamping and labelling the jars, and finally storing the jars in the cellar (Murray, 2000; Guasch-Jané, 2008). In the scene from Nakht's tomb (Figure 1) at Thebes, dating to the Eighteenth Dynasty (1539-1292 BC), the grape harvest and winemaking are represented. To the right, the grape harvest: two workers picking up the red grapes by hand and putting them in baskets. To the left, the elaboration of wine: four workmen pressing the grapes in a vat with their bare feet and, besides this, there is a man taking the red must that flows out. On the top, the wine amphorae are sealed with a mud stopper.

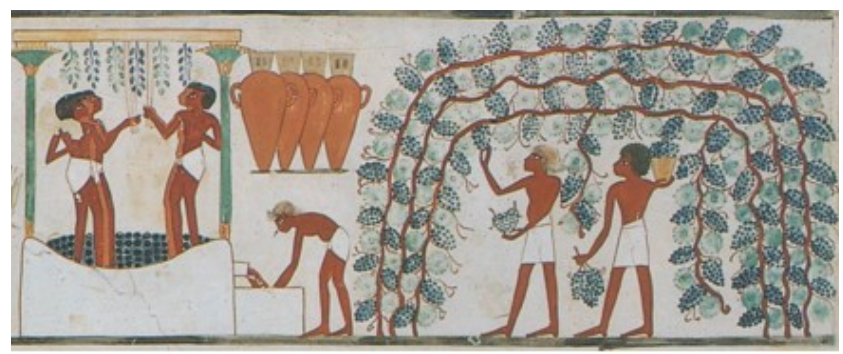

Figure 1. Nakht's tomb (TT52) in Sheikh Abd El-Qurna, Thebes

Regarding the presence of white grapes in the iconography, it is still under discussion. It has been suggested that a tomb of from Deir El-Bersheh of the Middle Kingdom Period (1975-1640 $\mathrm{BC}$ ) may show the production of white wine, since the pressing scene directly follows the harvesting scene where greenishcoloured grapes could be represented (Montet, 1913; Murray, 2000).

The elaboration of the shedeh represented in the scenes is also doubtful, and there is a unique reference from the tomb of Baqet III (no. 15) in Beni Hassan that might show a filtering and a heating process (Tallet, 1995).

Our project starts the documentation of the corpus of wine in ancient Egypt with the viticulture and winemaking scenes, not only because of the extensive information they provide, but also for many aspects that are less studied. The types and forms of the vines that are represented in the scenes, and the different heights of the vine tree or its shape are still not fully studied and classified. The same for the workers involved in the grape harvest, the way they picked the grapes as well as the kind of baskets they used for transporting the grapes to the press.

Furthermore, the type and material of the press (or deposit) where the grapes were treaded needs to be studied in-depth, because these scenes are the only references as no archaeological evidence has been found. Another aspect we aim to study is the extraction of the juice (and colour) using a sackpress. 
The fermentation process and the closing of the wine-jars, or the strict control of closing and labelling wine-jars during the New Kingdom Period, revealed by the amphorae and their inscriptions, are even more interesting aspects to be investigated.

\subsection{Documentation and archives}

The project information was gathered in the archives of the Griffith Institute and Sackler library in Oxford University, the British Museum and Egypt Exploration Society (EES) in London, and in on-line libraries such as the Institut Français d'Archéologie Orientale (IFAO), the German Archaeological Institute (DAIK), the Theban Mapping Project website, the Online Egyptological Bibliography (OEB), the Brooklin Museum library, the Aegyptus catalogue from München University, among others.

The Porter and Moss (1852-1941) collection, which includes all the tombs in Egypt, as well as the Journal of Egyptian Archaeology (JEA), the Excavation Memoirs and Archaeological Survey Memoirs of the EES, Mémoires de l'Institut Français d'Archéologie Orientale (MIFAO), Bulletin de l'Institut Français d'Archéologie Orientale (BIFAO) series, among others, were consulted to identify the tombs having scenes of viticulture and winemaking.

\section{THE DATABASE}

\subsection{Bibliographical database}

Our team is developing a database in two different parts: the bibliography and the scenes of viticulture and winemaking. The bibliographical database, which has now more than 197 entries, includes the following items about each reference: serial number, type of article/book, authors, title, website, online link, periodical/ journal/ encyclopaedia/ dictionary, edition, editors, pages, plates/ plans, publisher, place of publication, year of publication, author abbreviation and remarks (Fonseca, 2012; Guasch 2012). It is being recorded in Excel Sheet and presented by Filemaker Pro11 software.

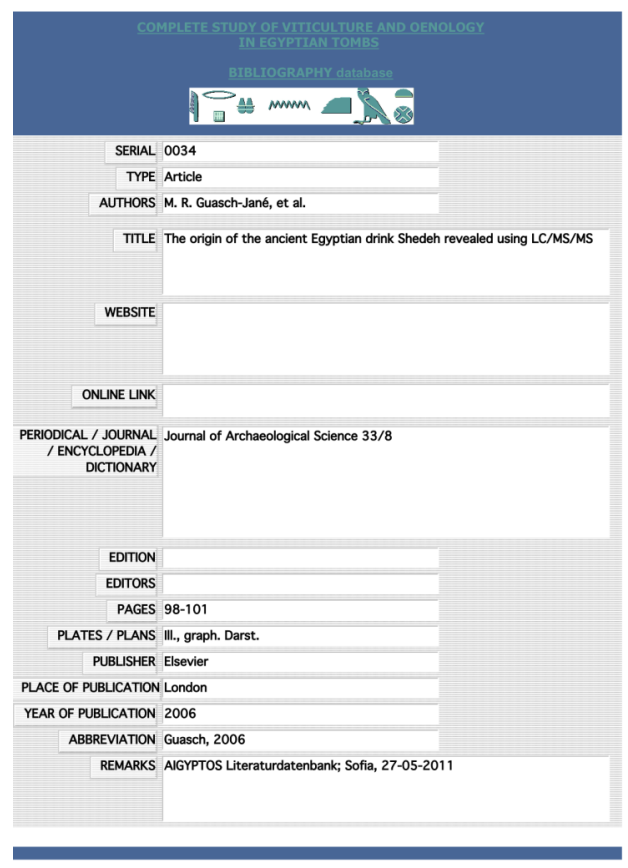

Figure 2. Bibliographic database

\subsection{Scene-detail database}

The database of the scenes of viticulture and winemaking in the ancient Egyptian private tombs (Fonseca, 2012; Guasch 2012), in process, will include the following items about each scene: record number, scene description with the different steps according to the theme, that is, viticulture or winemaking. The steps represented in the viticulture scenes include: vinery, taking care of the vine, grape harvest and counting the baskets. In the winemaking scenes, the steps represented are: transporting grapes to a press, pressing grapes, heating and filtering, pressing the remains in a sack press, filling wine jars, fermentation, offerings to goddess Renenutet, wine tasting, sealing the wine jars, labelling wine jars, counting wine jars, transporting wine jars to a cellar, refrigeration during fermentation, and storing wine jars in a cellar.

The scene-detail database will also include scene details: annotations, scene type and scene condition, text (inscriptions and translation) and image/photo. Moreover, the dating (period, dynasties and kings), provenance (governorate, archaeological site, tomb name and number, and location inside the tomb) and present location (if it is the same as provenance, if it's a museum then location inside the museum and inventory number, and others if it's not a museum) will be detailed. Finally, the tomb information: type of tomb, tomb's owner (names and titles of the tomb's owner) will be included. At the end, the bibliographical references related to the scene will be listed. The data is being recorded in Excel Sheet and presented by Filemaker Pro11 software.

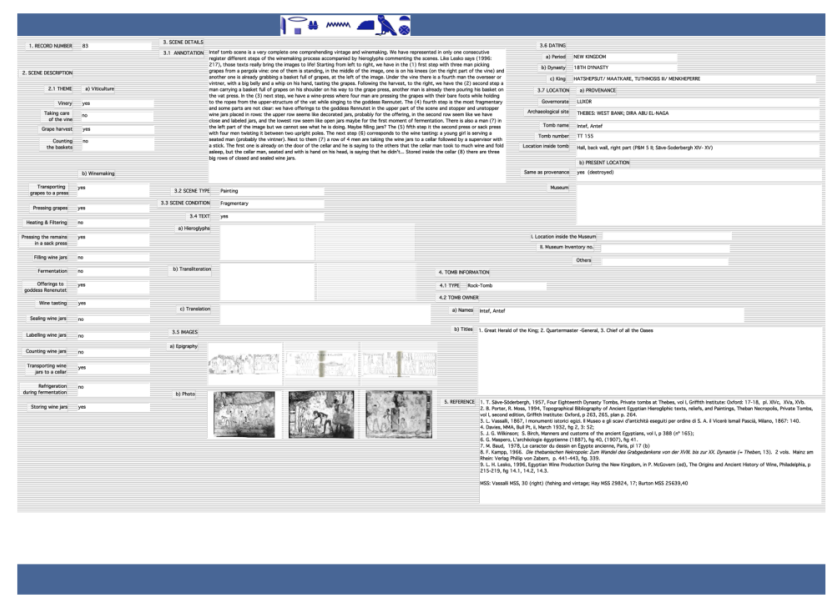

Figure 3. Scenes database

\subsection{Photographic work}

The bibliographical research of the scenes of viticulture and winemaking has resulted in the identification of some unpublished scenes. Furthermore, some of the scenes of viticulture and winemaking are not available for publication, because of copyrights or because they were never drawn or photographed. For this reason, and with permission of Dr. Mohammad Ismail, director of the Permanent Committee and Foreign Mission Affairs of the Supreme Council of Antiquities (SCA) of Egypt, we will start a photographic survey of the graves in May 2013. The photographic work of the scenes will permit us to complete the analysis of the scenes and texts associated to those scenes. We are planning to start the mission in Upper Egypt (Luxor, Aswan and Sohag). We have 49 tombs in Luxor (9 unpublished scenes), 2 tombs in Aswan and 1 tomb in Sohag. 
Once we finish this part of the survey we plan to continue with the rest of tombs having viticulture and winemaking scenes that we have identified in the rest of Egypt. In Middle Egypt, there are 2 tombs in Asiut, 8 tombs in Miniya and 2 in Beni Sueif. In Lower Egypt, there are 25 tombs: 10 in Giza necropolis, 11 in Saqqara necropolis, 1 in Abusir and 1 in Bahariya oases.

\section{TECNOLOGY TRANSFER AND DISSEMINATION}

\subsection{The website}

Besides the database with the corpus of viticulture and winemaking scenes and the bibliography at the first stage, the project is developing a website, that will be accessible through the URL http://www.wineofancientegypt.com, and will include all the material related to the research and the scientific and non-scientific dissemination of the results.

Regarding the technical aspects, the web will be multiplatform and available for consultation through mobile devices: tablets and $3 \mathrm{G}$ mobiles. The $\mathrm{Qr}$ codes have been generated to allow the consultation through these devices.

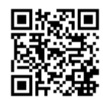

The platform language is based on XML (eXtensive Markub Language). The web interface is designed using Content Management System (CMS) with open code, a free software under General Public Licence, allowing an intuitive navigation and actualization of the contents of the website. The contents of the platform will be under licence of Creative Common BYNC-ND (Attribution-NonComercial-NoDerivs).

The website creation is financially supported by the VINSEUM, Museu de les Cultures del Vi de Catalunya [www.vinseum.cat] and developed by Sistemes de Gestió de Patrimoni (SGP) [www.sgponline.net].

The web platform will give visibility to our project, an open access to the database, which will be georeferenciated, and the dissemination and socialization of the archaeological knowledge in relation to wine in antiquity as well as bibliography and multimedia material (images, audiovisual) and 3D reconstructions. The use of the Information and Communications Technology (ICT) will allow dissemination and on-line consultation.

The website contents will include the general information about the project (introduction, history, objectives and methodology), the team members, publications (papers, articles and communications), bibliographies, the scene-detail database, news, links, collaborations and contacts.

The research papers that we plan to publish in international peer-reviewed journals with the results of the scientific research will be included in our website. Articles presenting the results and addressed to the public will be also incorporated in the website of the project, as well as articles in journals specialised in Egyptology, archaeology or oenology, magazines and in the mass media. Furthermore, the communications in congresses presenting the research results of this project will be posted in the website, as well as conference proceedings, and lectures to the scientific community and to the general public.

The English will be the main language of the website and of the database, but the contents will be translated into Portuguese, Catalan and Arabic languages as well and available through the website. Lately, French and Spanish will be also included.

\subsection{Further research}

We plan to extend our research to the other aspects related to wine that are represented in the ancient Egyptian iconography: the scenes of wine drinking in banquets and religious festivals. Scenes depicting wine consumption were popular motifs in private tombs of the Eighteenth Dynasty (1539-1292 BC) at Thebes. Furthermore, we also aim to document the scenes of wine-offering in rituals depicted in tombs and temples, as well as the archaeological artefacts (wine jars and related objects) which will be further included in the website. The expected results are to relate the process of wine elaboration of the ancient Egyptians to the traditional European method, and its possible influence, and to unveil the ancient Egyptian wine culture legacy in the Mediterranean through the compilation and study of the iconography, texts and artefacts.

\section{CONCLUSION}

The final and main result of the 'Irep en Kemet', Wine of ancient Egypt, project is to document the corpus of wine in ancient Egypt. We aim to identify the role and significance of ancient Egyptian wine in the wine history and to highlight its influence on Greek, Roman and European wine culture. The scenes of viticulture and winemaking reflect the complexity of the winemaking procedures developed by the ancient Egyptians. The different steps of the wine elaboration represented in the reliefs and paintings have been identified and compared with the modern ones.

We aim to publish an on-line comprehensive and researchable database of the viticulture and winemaking scenes in the ancient Egyptian tombs, considering all the data regarding the scene and the tomb where it was found, and the bibliographical references available, and to have all the images to be able to study them together with the texts attached to those images. At this stage, we are compiling and studying the viticulture and winemaking scenes in the Egyptian private tombs and we have started the photographic mission in the Egyptian tombs having scenes of viticulture and winemaking. Moreover, the website of the project (www.wineofancientegypt), with the project's objectives, details, dissemination and main results, is available on-line. Later on, the database will be included and it will be accessible for Egyptologists, students or the general public interested in this subject. Furthermore, we plan to extend our project to include all the scenes related to wine in the ancient Egyptian daily life and rituals, depicted in temples and on funerary stelae and artefacts.

\section{REFERENCES}

Athenaeus (I, 33 d-f), 1961. Athenaeus, The Deipnosophists, with an English translation by Charles Burton Gulick, Loeb Classical library, Vol. I. Harvard University Press, London, pp. 146-147.

Černy, J., 1965. Wine jars. Baines J. (Ed.), Hieratic Inscriptions from the Tomb of Tutankhamun, Tutankhamun's Tomb Series, Vol. II. Griffith Institute, Oxford, pp. 1-4.

Derchain, P., 1965. Le papyrus Salt 825 (B.M. 10051): Rituel pour la Conservation de la Vie en Égypte, Mémoires Vol. LVIII: 137 (II, 1), 147-149 (n. 10). Académie Royale de Belgique, Bruxelles, pp. 137, 147-149.

Erman, A., Grapow, H., 1926. Irep. In: Wörterbuch der ägyptischen Sprache, Vol. IV. Akademie Verlag, Leipzig, p. 115.

Erman, A., Grapow, H., 1930. Shedeh. In: Wörterbuch der 
ägyptischen Sprache, Vol. IV. Akademie Verlag, Leipzig, p. 568.

Fonseca, S., Ibrahim, M., 2012. Documentation of viticulture and winemaking in the Egyptian tombs. In: Congress Jovens em Investigação Arqueológica (JIA) 2011 Proceedings, University of Faro, Portugal, pp. 17-22.

Guasch-Jané, M.R. (et al.), 2004. Liquid chromatography mass spectrometry in tandem mode applied for the identification of wine markers in residues from ancient Egyptian vessels. Analytical Chemistry, 76, pp. 1672-1677.

Guasch-Jané, M.R. (et al.), 2006a. The origin of the ancient Egyptian drink shedeh revealed using LC/MS/MS. Journal of Archaeological Science, 33, pp. 98-101.

Guasch-Jané, M.R. (et al.), 2006b. First evidence of white wine in ancient Egypt from Tutankhamun's tomb. Journal of Archaeological Science, 33, pp. 1075-1080.

Guasch-Jané, M.R., 2008. Wine in Ancient Egypt: a Cultural and Analytical Study, British Archaeological Reports S1851. Archaeopress, Oxford, pp. 11, 29-30, 53-54, 56-59.

Guasch-Jané, M.R., 2010. On Egyptian wine marketing, A. Hudecz, and M. Petrik (Ed.): Commerce and Economy in Ancient Egypt, Proceedings of the Third International Congress for Young Egyptologists 25-27 September 2009, Budapest. British Archaeological Reports S2131. Archaeopress, Oxford, pp. 63-69.

Guasch-Jané, M.R., 2011. The meaning of wine in Egyptian tombs: the three amphorae in Tutankhamun's burial chamber. Antiquity, 85(329), pp. 851-858.

Guasch-Jané, M.R. (et al.), 2012. 'Irep en Kemet' project: creating the corpus of wine in ancient Egypt. In: Fourth International Euro-Mediterranean conference (Euromed 2012) on Cultural Heritage and Digital Libraries, Amathus (Cyprus), October 29-November 3 2012, International Journal of Heritage in the Digital Era 1(1), Multi Science Publishing, pp. 181-186.

James, L., 1996. The earliest history of wine and its importance in ancient Egypt. In: McGovern P.E., Fleming S.J., Katz S.H. (Eds.), The origins and ancient history of wine, Food and Nutrition in History and Anthropology, Vol. 11. Routledge, Amsterdam, pp. 197-213.

Lesko, L., 1996. Egyptian wine production during the New Kingdom. In: McGovern P.E., Fleming S.J., Katz S.H. (Eds.), The origins and ancient history of wine, Food and Nutrition in History and Anthropology, Vol. 11. Routledge, Amsterdam, pp. 215-230.

Lerstrup, A., 1992. The making of wine in Egypt. Göttinger Miszellen, 129, pp. 61-82.

Meyer, Ch., 1986. Wein. In: Lexikon der Ägyptologie, Vol. VI. In: Helck W., Westendorf W. (Eds.), Harrassowitz, Wiesbaden, pp. 1169-1182.

Montet, P., 1913. La fabrication du vin dans les tombeaux antérieurs au nouvel empire. Recueil de Travaux Relatifs a la Philologie et a l'Archéologie Égyptiennes et Assyriennes, Vol. 35. Franck, Paris, pp. 117-118.
Murray, A. M. (et al.), 2000. Viticulture and wine production. In: Nicholson, P.T., Shaw I. (Eds.), Ancient Egypt Materials and Technology, Cambridge University Press, Cambridge, pp. 577- 608 .

Poo, M-Ch., 1995. Wine and wine offering in the religion of ancient Egypt. Helck W., Westendorf W. (Eds.), Kegan Paul Internacional, London, pp. 149-151.

Poo, M-Ch., 1986. Weinopfer. In : Lexikon der Ägyptologie, Vol. VI, Helck W., Westendorf W. (Eds.), Harrassowitz, Wiesbaden, pp. 1186-1190.

Porter, B., Moss, R., 1852-1941. Topographical Biliography of Ancient Egyptian Hieroglyphic Texts, Reliefs and Paintings, IVII vols. Griffith Institute, Oxford.

Tallet, P., 1995. Le shedeh: etude d'un procédé de vinification en Égypte ancienne. BIFAO, 95, pp. 459-492.

Tallet, P., 1998. Le vin en Egypte à l'époque faraonique. Unpublished PhD. Université de Paris-Sorbonne, Paris, pp. 356397.

Tallet, P., 2010. De 1'ivresse au dégrisement: à propos d'un article récent sur le vin shedeh. Göttinger Miszellen, 227, pp. 105-112.

Wegner, M., 1933. Stilentwickelung der Thebanischen Beamtengräben. MDAIK 4, pp. 38-164.

\section{ACKNOWLEDGEMENT}

This project «PTDC/HIS-ARQ/112562/2009» is financially supported by the Fundação para a Ciência e a Tecnologia (FCT), Ministério da Educação e Ciência in Portugal.

We would like to express our gratitude to Xavier Fornos, director of the VINSEUM, Museu de les Cultures del Vi de Catalunya, for the financial support of the project's website and Josep Socorregut, executive director of Sistemes de Gestió del Patrimoni (SGP), for the website development. 